\title{
Central Java Shooting Sports Training Center Management In the 2020 Pandemic
}

\author{
Mugiyo Hartono \\ \{mugiyohartono@mail.unnes.ac.id\} \\ Universitas Negeri Semarang, Semarang, Indonesia
}

\begin{abstract}
The purpose of this study to analyze the planning, organizing, implementing, and monitoring systems of Shooting Sport PELATDA during the pandemic. The research method used is descriptive qualitative at the Provincial Board of PERBAKIN, Central Java. The results of this study are replanning in various aspects, namely training organization, duties of trainers, support for training facilities, and programs. Exercises with a design of independent exercises at home. The management of equipment is also a difficult issue that has an impact on funding; the implementation aspect requires adjustments that require time and role of the coach. Nonstandard facilities and even; the aspect of supervision, especially the trainers in monitoring the. The training results report was sent via photos or videos not be used optimally in evaluating the athlete's performance in training. The conclusions in this study are replanning and changes in the organizing system in the shooting sport.
\end{abstract}

Keywords: Training center management, shooting, sports.

\section{Introduction}

The world was shocked by the emergence of diseases caused by the Corona virus or commonly known as Covid-19 (Corona Virus Diseases-19). This virus began to plague and then spread to all corners of the world very quickly including in Indonesia, so that WHO designated this outbreak as a global pandemic. This disease has a major impact in all aspects of life, including in the world of sports in all forms of organizing activities including sports training which are temporarily stopped and carried out with limitations to prevent and break the chain of transmission of Covid-19. Therefore, a special management of sports organizations is needed in responding to the developments that have occurred due to Covid-19.

Sports management is an amalgamation of skills that are correlated with aspects of planning, organizing, leadership, controlling, budgeting, and evaluating in an organization which has the main ingredient as a sport-related resource [1]. The benefits of sports management are shown through how the success of a person's ability to manage, lead and simultaneously foster a sports organization [2], in which sports organizations cover various fields which are important parts that must be controlled so that they can be used as tools to achieve goals. end of the organization. The ultimate goal of sports management is to achieve victory for its athletes in participating in a championship both nationally and internationally.

The Central Java shooting sport branch is under the guidance of the Central Java PERBAKIN Provincial Board, which is one of the leading sports of many sports prepared by KONI in Central Java province to participate in the National Sports Week (PON) which will be 
held in October 2021 in Papua. Shooting as one of the leading sports is expected to achieve maximum performance and get a gold medal in the upcoming PON, so that this sport must carry out regional training camps seriously through planned and continuous training programs carried out in a Regional Training Center program. (PELATDA) Central Java in preparation for the XX PON in 2021 in Papua.

PELATDA PON XX, which has been implemented since 2018, is carried out with a decentralized system that is concentrated in various regions of Central Java according to the domicile of the area where athletes live, including those carried out by the shooting sport. As time went on in early 2020, to be precise in March, Indonesia was faced with the conditions of the Covid-19 Pandemic, which forced us all to adhere to strict health protocols and not be allowed to carry out activities outside the home, including shooting athletes who were running PELATDA which have to carry out the exercises in their respective homes.

During the Covid-19 pandemic, the training process for shooting athletes in Central Java was not normally carried out, the implementation of face-to-face training together in one training ground on the shooting range turned into independent training in their respective homes, so that the training program automatically previously planned by the coach, changes must be made to suit the existing conditions, namely independent training using limited facilities in the homes of each athlete. Likewise, the coaching team will certainly redesign and make new formulations of technical assistance, monitoring and evaluation of training programs that are being and have been carried out by athletes in order to be effective, at least to maintain the conditions already owned by shooting athletes.

Fostering shooting athletes like other athletes in other sports, in an effort to achieve optimal performance within a certain time target must continue to be carried out, despite the situation and conditions of the Covid-19 pandemic which must be faced with limitations in various aspects for the benefit of health and safety. Athletes still have to do intensive training even in conditions of limitation, this is none other than so that the athlete does not lose the performance and physical condition they have achieved which was built in the long process of the previous few years. Likewise, in this case, if the training is not continuous, it will have an impact on decreasing achievement and can also have an impact on the athlete's inability to achieve peak performance at the predetermined target time of the main match.

The Covid-19 pandemic does not only affect the problem of shooting training programs for athletes and the problem of coaches who are forced to reformulate the implementation of training programs only, but with the limited training facilities / infrastructure in the homes of each athlete, it becomes a problem that is not easy and quickly resolved. Then what is no less important is another aspect that is a factor that influences the implementation of training for shooting athletes, namely the aspect of the availability of funds to support the program to run well. Financial factors are very much needed to support and back up all the necessary needs, both for the provision of training infrastructure, consumption and supplements for athletes, incentives for athletes and coaches, and other needs especially in conditions of the Covid-19 Pandemic which were never planned before. so that there is a need for a specific policy in responding to it. According to Griffin [3], management is a series of activities (including planning and control) directed at organizational resources (human, financial, physical, and information) to achieve organizational goals in an effective and efficient manner. in other words, management is a tool used to achieve the desired goals, it appears that management is always applied in a relationship with a collaborative effort or a group of people in an organization.

The problems described above are in important aspects that affect the development of achievement and the implementation of regional training camps for shooting, each of which cannot be separated from the frame in the broad framework of the management of the Central 
Java shooting sport Pelatda organization, which in its management requires the application of good management functions and discipline to achieve the expected organizational goals, namely maximum achievement for shooting athletes in the XX PON in 2021 in Papua. In order for the implementation of the management function to run well, it requires management elements that are interrelated with one another. According to George R. Terry in his book Principle of Management, there are six main resources of management, namely: (1) Man; (2) Materials; (3) Machines; (4) Methods; (5) Money; and (6) Market.

Therefore, to find out to what extent the implementation of Pelatda in the Central Java Shooting sport branch in 2020 during the Covid-19 pandemic, a critical evaluation step is needed so that existing problems can be found to find the best solution through the management process approach, namely by looking at how far. implementation of the management function of management resources in the Central Java Shooting Central Java Regional Training Center in 2020 .

The formulation of the problems in this study are as follows: 1) How is the regional training center (PELATDA) resource planning system for Central Java Shooting during the Covid-19 Pandemic in 2020; 2) How is the regional training center (PELATDA) resource organizing system for Central Java Shooting during the Covid-19 Pandemic in 2020; 3) What is the system for implementing the Regional Training Center (PELATDA) resource for Central Java Shooting during the Covid-19 Pandemic in 2020; 4) What is the monitoring system for the Regional Training Center (PELATDA) shooting sport in Central Java during the Covid-19 Pandemic in 2020 .

The objectives of this study are as follows: 1) To analyze the regional training center (PELATDA) resource planning system for Central Java Shooting during the Covid-19 Pandemic in 2020; 2) Analyzing the resource organizing system for the Regional Training Center (PELATDA) for the Central Java Shooting sport during the Covid-19 Pandemic in 2020; 3) Analyzing the regional training center (PELATDA) resource mobilization system for Central Java Shooting during the Covid-19 Pandemic in 2020; 4) Analyze the monitoring system for the Central Java Regional Training Center (PELATDA) shooting sport during the Covid-19 Pandemic in 2020.

\section{Method}

The research design and approach used in this study is a qualitative approach, because the data collected is in the form of words, pictures, and not numbers [4]. This qualitative research approach describes the results of the analysis through the design of a management process, namely the implementation of a planning system, an organizing system, an actuating system and a controlling system, on resources or management elements. during the Pandemic in 2020, which consists of organizational /committee aspects, human resources, training programs, infrastructure, and funding.

The data sources of this research are all those that can provide information about the management of the Central Java shooting sports training center in 2020. The research data is in the form of written or spoken words, photos or actions obtained from data sources, namely people, writing, and places. This is in line with Arikunto's [5] opinion that data sources are obtained from three objects, namely, person, place, paper.

Data collection techniques by observation (observation), interviews (interview), and documentation, as well as a combination (tringulation). To obtain primary data, data collection 
tools are used in the form of observation (observation) and interviews (interview), while documentation in the form of archives is used as supporting data or secondary data. Drawing conclusions in this study in addition to using data triangulation can also use the rubric of sports coaching management categorization.

In this study, researchers used participatory observation. namely by observing the activities of the subject at the Central Java Provincial Board of Commissioners in Central Java and at the training ground and infrastructure as well as at home. Arikunto stated that observation or what is also called observation includes sight, smell, hearing, touch and taste [6]. Interviews in this study were conducted by researchers with the committee of Pelatda, coaches, athletes, who could provide information about the management of the central Java shooting sports training center. Documentation consists of various things that can help collect research data. The documentation in this study includes: the organizational structure of the regional plate committee, trainer qualifications, training programs, infrastructure data, athlete data, and budget.

The data analysis technique used is the analysis in the field with the Miles and Huberman model. Miles and Huberman [7], suggest that "activities in qualitative data analysis are carried out interactively and continue to completion, so that the data is saturated". In other words, the actual data analysis was carried out by researchers since they started collecting data. During the interview, the researcher directly analyzes the answers from the informants to ensure that the answers are satisfactory to answer the problem formulation. Activities in data analysis using the Miles and Huberman model include data reduction, data dispaly, and conclusion drawing / verification. The analysis steps are shown in the following chart:

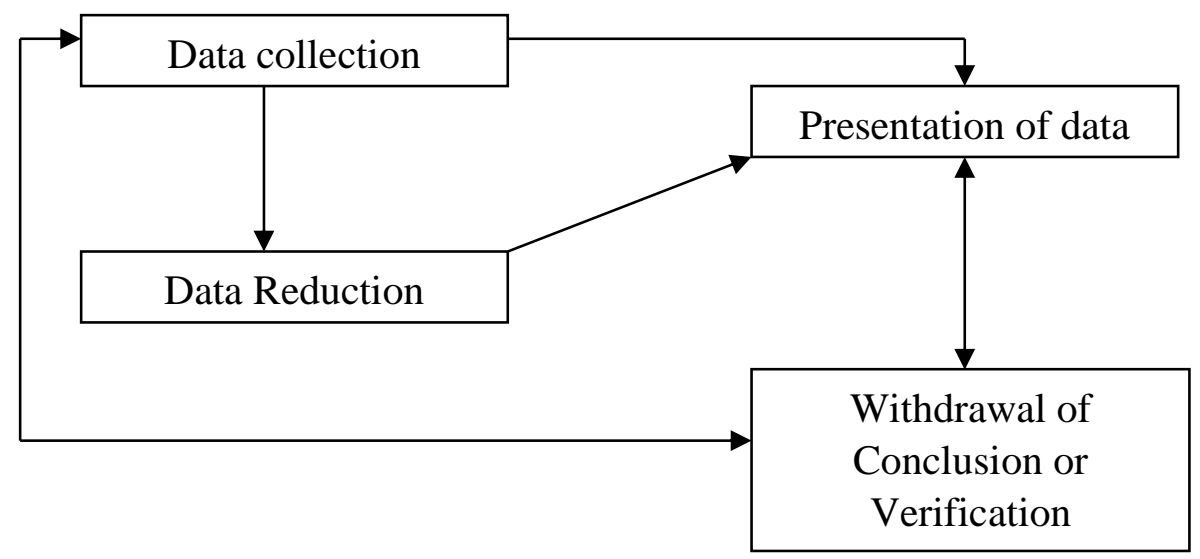

Fig. 1. Data analysis method

The data obtained through interviews is of course very large in number, therefore the data obtained must be immediately analyzed through data reduction. According to Sugiyono states that "reducing data means summarizing, selecting main things, focusing on important things, looking for themes and patterns and removing unnecessary" [7].

Data presentation in qualitative research can be in the form of descriptions, abbreviations, tables, charts, graphs, flowcharts, pictograms, and so on. According to Sugiyono [7] states that "by displaying data, it will be easier to understand what happened and plan the next work based 
on what is understood". The data that has been reduced is a collection of data from interviews with sources.

The final step in data analysis for Miles and Huberman's model is drawing conclusions and verification. Based on the data that has been presented, the researcher is able to draw a conclusion that is still temporary. When the conclusion is supported by strong evidence in the field, then the conclusion is creative.

\section{$3 \quad$ Results and discussion}

\subsection{Management organization}

Committee with an organizational structure consisting of elements from the chairman, secretary, treasurer, engineering, training, monitoring / evaluation and general affairs. This committee is formed and designed so that it can organize and manage the central Java shooting sports training center activities so that it can run well as planned. Written documents that can be used as the basis for this committee to work are the Decree of the General Chairperson of the Central Java Perbakin Province and a description of the duties according to the main duties and functions of each position in the organization.

In its implementation, each individual committee member is on average active and can carry out their respective main tasks and functions, even though there are still some personalities who cannot work optimally, because they have to divide their duties with their main work and several other activities that are carried out, However, in terms of work responsibilities, it can be said that the average is good in the context of sports organizations [8].

In terms of supervision of the committee's performance, it is still weak, because no one has been specifically assigned to do that, considering that the committee personnel also include the management personnel of the Central Java Perbakin Province, so the committee cannot independently carry out its duties so it is still very subjective.

\subsection{Exercise program}

Planning for the training program has been prepared since the beginning of the training camp for the shooting sports area. The training program was prepared for the purpose of shooting athletes with high achievements at the XX PON 2020 in Papua, which at that time was planned to take place in October 2020 when the Covid-19 pandemic had not yet emerged, so that the idealism of the program design was in such a way both from physical and technical aspects. , strategy, and mental. However, when the Covid-19 pandemic entered Indonesia and the government gave instructions to anticipate by stopping all face-to-face activities including training, as well as the implementation of PON XX was postponed in 2021, the training program was reconstructed according to the conditions of the Covid-19 Pandemic which required a protocol. strict health with existing limitations, namely exercises carried out independently in each house.

The change in training from face-to-face together with other athletes on the shooting range, changing to self-training independently in each house, makes something new and unexpected and never thought of before, so what kind of training program is it? can be effectively run by athletes making it a trial and error training program provided by the coach [9]. 
The organization of training programs during the Covid-19 pandemic that was found in the field was still very tattered, especially in the early days of the pandemic, given the lack of integration between physical, technical and mental aspects which are important aspects of shooting athlete training. During a pandemic, what is prominent in athlete training is the physical aspect because training can be easily done independently with limited space. Most of the technical and mental training programs cannot be carried out by shooting athletes maximally due to the lack of training facilities and infrastructure, besides that there is no motivation because the training must be done alone, without a companion, and the supervision of the coach.

Monitoring and evaluation of training programs carried out by coaches during the pandemic is by sending training photos and videos, as well as the results of scoring which are carried out periodically by athletes, so that the form of supervision carried out with such a model is certainly less valid and difficult to accounted for. In general, the training program for shooting athletes during the Covid-19 pandemic in 2020 did not work well and resulted in not maximizing training outcomes, this can be seen from the scoring document that is periodically carried out by athletes [10].

\subsection{Human Resources}

The recruitment system of a coach and / or assistant coach selected to handle the Central Java shooting training training program, is not carried out with procedures and uses objective criteria. Recruitment is carried out on the basis of a habit that has been going on for years without an evaluation of the previous coach's performance. Trainers who are active in the Perbakin shooting range in the GOR Jatidiri complex have the highest chance of being appointed as coaches, because of their habit and as if it has become a culture that has been running from year to year, so it can be said that for years the shooting coaches in Central Java were only dominated by certain people only.

Organizing the work of coaches in carrying out their daily tasks is not well planned, because due to the absence of competition in coach recruitment, the work of coaches has become routine, so that there are no serious challenges and efforts in handling athletes. Structurally there is a coaching organization, namely there is a head coach, coach and assistant coach, but in its implementation in the field the structure has not functioned properly. One of the causes of this is the lack of proper functioning of the supervisory system for the performance of the trainers carried out by the Central Java Perbakin management [11].

The athlete recruitment system can be said to be very objective considering the athletes selected on the basis of passing the national selection with the Minimum Qualification Score (MQS) system. Based on the MQS system, athletes have the opportunity to take part in the XX PON in 2021, but not automatically because it still has to be determined by the quota given to an area by PB Perbakin. Likewise, competition is still being carried out to become who is the best from the athletes who have passed through the MQS system.

The organization and implementation of shooting athletes who are members of the Central Java Shooting Center, strictly that the competition to be promoted and relegated is carried out on the basis of the results of athletes' achievements from the scores achieved through periodic scoring tests or the results of the championships they are participating in, so that the relegation system and athlete promotion can be said to be very objective [12].

Objective supervision of athletes' achievements can be seen from the achievements they have achieved within a certain period of time, in addition, direct supervision is carried out by coaches who accompany athletes in routine training. During the pandemic, the policy on athlete 
treatment is no different from the conditions before the Covid-19 pandemic, so that the previously implemented system can be carried out according to initial planning.

\subsection{Training infrastructure}

Training facilities and infrastructure for shooting athletes can be said to be expensive compared to several other sports. For example, for means or better known as equipment, shooting sports such as weapons and their devices attached to athletes are absolutely must be owned by shooting athletes personally, considering that weapons with their equipment, including special clothes worn by athletes, cannot be used interchangeably with other athletes. , especially for athletes who are included in the Pelatda shooting program who are actually the best athletes in Central Java, that the weapon is a very important personal tool in which a shooting athlete must recognize well the characteristics of the weapon he is wearing.

In addition to weapons, bullets to support athlete training must always be sufficiently available, considering that shooting sports are a type of precision sport that requires training with a high frequency and intensity of shooting, so that the presence of bullets is absolutely available in large quantities. The calculation of the need for bullets can be planned in advance so that you can predict exactly how many bullets for each athlete in carrying out training in a certain time.

Inventory equipment in the form of weapons, both long-barreled guns and pistols owned by the Central Java Perbakin Province, is mostly used for beginner athletes who are still learning basic shooting, so that shooting athletes who have achieved absolutely do not use inventory equipment [13].

Infrastructure or better known as venues or training venues in the form of buildings and shooting ranges with various equipment attached, in shooting sports have specifications and specificities because the form of shooting ranges and buildings equipped with existing facilities have rules that must be met both technically and security. Pengprov Perbakin Central Java has a shooting range of 10 meters indoor, 25 meters and 50 meters outdoor with the equipment attached to the infrastructure in question. The current condition of the field that is most suitable for use is a field for a distance of 10 meters indoors, for another shooting range that is in renovation condition because it is not suitable for training and holding championships.

In the situation and conditions of the Covid-19 pandemic which require athletes to train independently in their respective homes, athletes cannot exercise ideally, because training cannot use standard and eligible venues / shooting ranges, and are not supported by suitable venue equipment. adequate, thus it can be ascertained that it will greatly affect the achievements of athletes. For athletes who do not have a home shooting training ground they only do "dry" drills without using bullets, making it difficult to know the exact extent of the shot. In the current condition of athletes who only do a lot of physical exercise for months, there will be a feeling of burnout and a decrease in motivation in doing independent training.

\subsection{Funding}

Provision of funds to support the implementation of shooting training training center programs is very important and absolutely must be available and sufficient. The need for shooting training athletes that absolutely must be supported is the fulfillment of ammunition or bullets, gas for air guns, special clothing for long-barreled athletes, consumption needs and additional food during training, other supplements for athletes, recreational support / refreshing 
athletes, provision of equipment. special needs at home for independent training during the Covid-19 pandemic, and other needs.

Planning for funding needs during the implementation of the training center program can be predicted in advance by carrying out calculations according to the needs set forth in the form of an activity Budget and Expenditure Plan (RAB), which can then be implemented according to its use and managed according to the main duties of the Pelatda committee.

In terms of the use of the budget, supervision is carried out by the leadership and treasurer of the committee which in a certain period of monitoring and evaluation is carried out together with other committee members, which will then be followed up by reporting the use of the budget to the chairman of the Central Java Perbakin committee and accountable to the Central Java Province KONI who provide Pelatda funding assistance.

Funding support is obtained from several parties, including from the Central Java Province KONI in the form of assistance for incentives for managers, coaches and athletes routinely received every month, training operational funds, rental assistance and maintenance of training sites, support for training and competition equipment and equipment, support for testing either in the form of try-ins or try-outs. Financial support from the Central Java Province KONI is not sufficient for all athletes' needs while running a long-term training program, therefore additional funds are still needed to cover the budget shortfall, which is supported by funding from the Central Java Perbakin Provincial Management budget, and from individual donors.

\section{Conclusions}

The conclusions in this study are 1) during the Covid-19 epidemic, re-planning was carried out in all aspects of activities in supporting the training center of Central Java Shooting athletes, both from the management side by the Pelatda committee, from the aspect of human resources, especially coaches and athletes in providing assistance and training. exercise supervision that is carried out independently, training programs that must be adapted to training independently at home, training infrastructure facilities that can support athletes in carrying out training independently, as well as funding issues; 2) changes to the organizing system, especially the coordination of tasks and functions of the manager, as a coach as a companion and supervision as long as athletes exercise independently at home; 3) the implementation of training camps carried out by athletes independently in their respective homes becomes very ineffective, because athletes have to struggle alone in overcoming training problems, motivation decreases because there are no friends and coaches in together, which in turn affects the achievement of achievement in training; 4) the supervision carried out by the coach cannot be maximized because virtually, so it only relies on self-discipline and the care of parents around the athletes when practicing.

\section{References}

[1] Wawan S. Suherman. Pengembangan Kurikulum Pendidikan Jasmani. Fik UNY. 2001.

[2] George R. Terry Dan Leslie W. Rue. Dasar-Dasar Manejemen. PT.Bumi Aksara. 2014.

[3] Fahmi, I. Perilaku Organisasi. CV.Alfa Beta. 2013.

[4] Moleong, J Lexy, P. D. Metode Penelitian Kualitatif. PT. Remaja Rosdakaya. 2009.

[5] Arikunto, S. Dasar-Dasar Evaluasi Pendidikan. Jakarta. Bumi Aksara. 2009.

[6] Azwar, S. Metode Penelitian (Edisi Revisi). Yogyakarta: Pustaka Pelajar. 2006. 
[7] Sugiyono. Metode Penelitian Pendidikan Pendekatan Kuantitatif, Kualitataif, dan R\&D. Bandung: CV Alfabeta. 2010.

[8] Harsuki. Pengantar Manajemen Olahraga. Diterbitkan Fakultas Ilmu Keolahragaan, Universitas Negeri Yogyakarta. 2012.

[9] Siagian, P. S. Fungsi-Fungsi Manajemen. Bumi Aksara. 2005.

[10] Arikunto, S. Prosedur Penelitian Suatu Pendekatan Praktik. (Edisi Revisi). Jakarta: Renika Cipta. 2010.

[11] Hasibuan, M. S. Manajemen Sumber Daya Manusia. PT Bumi Aksara. 2001.

[12] Hasibuan, M. S. Manajemen Dasar, Pengertian Dan Masalah (2nd Ed.). PT. Gunung Agung. 1996.

[13] Arikunto, S dan Safrudin, C. Evaluasi Program Pendidikan. Jakarta: PT Bumi Aksara. 2014. 